University of Wollongong

Research Online

Faculty of Engineering and Information

Faculty of Engineering and Information

Sciences - Papers: Part A

Sciences

$1-1-2015$

Dynamic wetting of CaO-Al2O3-SiO2-MgO liquid oxide on MgAl2O4 spinel

Hamed Abdeyazdan

University of Wollongong, ha984@uowmail.edu.au

Neslihan Dogan

University of Wollongong, ndogan@uow.edu.au

Muhammad Rhamdhani

Swinburne University of Technology

Michael Chapman

BlueScope Steel Limited, mchapman@uow.edu.au

Brian Monaghan

University of Wollongong, monaghan@uow.edu.au

Follow this and additional works at: https://ro.uow.edu.au/eispapers

Part of the Engineering Commons, and the Science and Technology Studies Commons

Research Online is the open access institutional repository for the University of Wollongong. For further information contact the UOW Library: research-pubs@uow.edu.au 


\title{
Dynamic wetting of CaO-Al2O3-SiO2-MgO liquid oxide on MgAl2O4 spinel
}

\begin{abstract}
Inclusion type and content in steel is critical in steelmaking, affecting both productivity through clogging, and downstream physical properties of the steel. They are normally removed from steel by reacting with a slag (liquid oxide) phase. For efficient inclusion removal, the inclusions must attach/bond with this liquid phase. The strength of the attachment can be in part characterized by the wettability of the liquid oxide on the inclusions. In this study, the dynamic wetting of liquid oxides of the CaO-Al2O3-SiO2-MgO system on a solid spinel (MgAl204) substrate with low porosity of 1.9 pct was measured at $1773 \mathrm{~K}\left(1500{ }^{\circ} \mathrm{C}\right)$ using a modified sessile drop technique. The dynamic contact angle between the liquid and solid spinel was determined for different $\mathrm{CaO} / \mathrm{Al} 2 \mathrm{O} 3$ mass percent ratios ranging from 0.98 to 1.55 . Characteristic curves of wettability $(\theta)$ vs time showed a rapid decrease in wetting in the first 10 seconds tending to a plateau value at extended times. A mathematical model for spreading behavior of liquid oxides by Choi and Lee was adopted and shown to provide a reasonable representation of the spreading behavior with time. The chemical interaction at the interface between spinel (MgAl204) and slag was analyzed by carrying out detailed thermodynamic evaluation and characterization using scanning electron microscopy/energy dispersive spectroscopy. There is evidence of liquid penetrating the substrate via pores and along grain boundaries, forming a penetration layer in the substrate. The depth of the penetration layer was found to be a function of substrate porosity and sample cooling rate. It decreased from $~ 350 \mu \mathrm{m}$ for $6.7 \mathrm{pct}-$ porous substrate to $\sim 190 \mu \mathrm{m}$ for substrate with porosity of $1.9 \mathrm{pct}$ and from $\sim 190 \mu \mathrm{m}$ to $\sim 50 \mu \mathrm{m}$ for a slow-cooled liquid oxide-spinel substrate sample in the furnace to a rapidly cooled liquid cooled-spinel substrate sample, respectively.
\end{abstract}

\section{Keywords}

mgo, sio2, al2o3, cao, spinel, wetting, mgal2o4, dynamic, oxide, liquid

Disciplines

Engineering | Science and Technology Studies

\section{Publication Details}

Abdeyazdan, H., Dogan, N., Rhamdhani, M., Chapman, M. W. \& Monaghan, B. J. (2015). Dynamic wetting of CaO-Al2O3-SiO2-MgO liquid oxide on MgAl2O4 spinel. Metallurgical and Materials Transactions B: Process Metallurgy and Materials Processing Science, 46 (1), 208-219. 


\title{
Dynamic Wetting of $\mathrm{CaO}-\mathrm{Al}_{2} \mathrm{O}_{3}-\mathrm{SiO}_{2}-\mathrm{MgO}$ Liquid Oxide on $\mathrm{MgAl}_{2} \mathrm{O}_{4}$ Spinel
}

\author{
HAMED ABDEYAZDAN, NESLIHAN DOGAN, M. AKBAR RHAMDHANI, \\ MICHAEL W. CHAPMAN, and BRIAN J. MONAGHAN
}

\begin{abstract}
Inclusion type and content in steel is critical in steelmaking, affecting both productivity through clogging, and downstream physical properties of the steel. They are normally removed from steel by reacting with a slag (liquid oxide) phase. For efficient inclusion removal, the inclusions must attach/bond with this liquid phase. The strength of the attachment can be in part characterized by the wettability of the liquid oxide on the inclusions. In this study, the dynamic wetting of liquid oxides of the $\mathrm{CaO}-\mathrm{Al}_{2} \mathrm{O}_{3}-\mathrm{SiO}_{2}-\mathrm{MgO}$ system on a solid spinel $\left(\mathrm{MgAl}_{2} \mathrm{O}_{4}\right)$ substrate with low porosity of 1.9 pet was measured at $1773 \mathrm{~K}\left(1500{ }^{\circ} \mathrm{C}\right)$ using a modified sessile drop technique. The dynamic contact angle between the liquid and solid spinel was determined for different $\mathrm{CaO} / \mathrm{Al}_{2} \mathrm{O}_{3}$ mass percent ratios ranging from 0.98 to 1.55 . Characteristic curves of wettability $(\theta) v s$ time showed a rapid decrease in wetting in the first 10 seconds tending to a plateau value at extended times. A mathematical model for spreading behavior of liquid oxides by Choi and Lee was adopted and shown to provide a reasonable representation of the spreading behavior with time. The chemical interaction at the interface between spinel $\left(\mathrm{MgAl}_{2} \mathrm{O}_{4}\right)$ and slag was analyzed by carrying out detailed thermodynamic evaluation and characterization using scanning electron microscopy/energy dispersive spectroscopy. There is evidence of liquid penetrating the substrate via pores and along grain boundaries, forming a penetration layer in the substrate. The depth of the penetration layer was found to be a function of substrate porosity and sample cooling rate. It decreased from $\sim 350 \mu \mathrm{m}$ for 6.7 pct-porous substrate to $\sim 190 \mu \mathrm{m}$ for substrate with porosity of $1.9 \mathrm{pct}$ and from $\sim 190 \mu \mathrm{m}$ to $\sim 50 \mu \mathrm{m}$ for a slow-cooled liquid oxide-spinel substrate sample in the furnace to a rapidly cooled liquid cooledspinel substrate sample, respectively.
\end{abstract}

DOI: $10.1007 / \mathrm{s} 11663-014-0207-8$

(C) The Minerals, Metals \& Materials Society and ASM International 2014

\section{INTRODUCTION}

UNDERSTANDING and controlling inclusion removal from steel is critical in modern steelmaking. ${ }^{[1]}$ Inclusions are usually formed as a reaction product of the steel deoxidation process, though they may also result from slag and mold flux entrainment, refractory degradation, or precipitation events on steel solidification. They are generally removed by reacting with a slag (liquid oxide) phase. This is primarily achieved by optimizing the process conditions to promote contact and reaction between the inclusion and liquid oxide. ${ }^{[2]}$ Efficient inclusion removal from steel is achieved when

HAMED ABDEYAZDAN, Ph.D. Student, and BRIAN J. MONAGHAN, Director of the Engineering Materials Strength, are with the Pyrometallurgical Research Group, School of Mechanical, Materials and Mechatronic, University of Wollongong, Wollongong, NSW 2522, Australia. Contact e-mail: monaghan@uow.edu.au NESLIHAN DOGAN, Lecturer, is with the Department of Materials Science and Engineering, McMaster University, Hamilton, ON L8S 4L7, Canada. M AKBAR RHAMDHANI, Lecturer, is with the Faculty of Science, Engineering and Technology, Swinburne University of Technology, Hawthorn, VIC 3122, Australia. MICHAEL W. CHAPMAN, Process Engineer, is with BlueScope Steel Ltd, Port Kembla, NSW 2505, Australia.

Manuscript submitted May 19, 2014. the inclusions contact the slag phase, leading to bonding and dissolution in the slag. If the bond is weak, then local fluid conditions are likely to result in the shearing of the inclusion-slag bond, and the inclusions remain in the steel. The strength of the inclusion bond or reactivity with slag may be assessed by measuring the dynamic wetting of the slag on a substrate made of the inclusion phase. ${ }^{[3]}$

Research on inclusion removal in steel refining is principally divided into categories of flotation of inclusion to the steel/slag interface, ${ }^{[4,5]}$ modification to improve reactivity/separation with the slag phase, ${ }^{[6]}$ and dissolution in the slag phase. ${ }^{[7-13]} \mathrm{A}$ number of previous studies relevant to inclusion dissolution in slags have been carried out on bulk refractory or ceramic materials ${ }^{[14-18]}$ where the material is dipped in slag and held for a period of time, removed, then analyzed for slag corrosion and/or penetration. Some recent studies have used high-temperature microscopy offering the possibility of analyzing the dissolution behavior of a single inclusion in a slag directly. ${ }^{[7-13]}$ Monaghan and Chen ${ }^{[7]}$ and Valdez et al. ${ }^{[12]}$ used high-temperature microscopy to investigate the effect of slag basicity on spinel inclusion dissolution. They found that the rate of dissolution of the spinel particles increased with increasing basicity of the slag. 
The least understood component of inclusion removal is inclusion reactivity/separation with the slag phase. ${ }^{[19]}$ The inclusion has to travel across the steel-slag interface to wet the slag. This is favored when contact angle $(\theta)$ for the steel inclusion is greater than $90 \mathrm{deg}$ (nonwetting) and when it is greater than $\theta$ for the inclusion slag. While it is understood that inclusion-slag interfacial tension/wetting plays a critical role in inclusion removal, there are only limited wetting data of slags on typical inclusion phase types in the literature. Recently, Choi and Lee ${ }^{[20]}$ investigated the wettability of alumina on slag and concluded that for a slag with a given $\mathrm{CaO} /$ $\mathrm{SiO}_{2}$ ratio, an increase in $\mathrm{Al}_{2} \mathrm{O}_{3}$ results in an increase in the wetting angle, $\theta$. This may in part be explained by the change in thermodynamic driving force of the reaction and/or a change in the physical characteristics of the slag with increasing alumina.

In this study, the dynamic contact angles of slags in the $\mathrm{CaO}-\mathrm{Al}_{2} \mathrm{O}_{3}-\mathrm{SiO}_{2}-\mathrm{MgO}$ system on a ceramic representing an $\mathrm{MgAl}_{2} \mathrm{O}_{4}$ spinel-type inclusion were measured using a modified sessile drop technique, similar to that used by Choi and Lee. ${ }^{[20]}$ In steelmaking, the presence of these inclusions causes productivity loss through the clogging of ladle shrouds and submerged entry nozzles as well as surface quality issues as a result of their high hardness. ${ }^{[21-30]}$ As part of this study, the slag-substrate interface and effects of substrate porosity on $\theta$ have been evaluated.

\section{EXPERIMENTAL}

The schematic of the sessile drop apparatus used to measure the contact angle is given in Figure 1. The slag and substrate were heated separately to $1773 \mathrm{~K}$ $\left(1500{ }^{\circ} \mathrm{C}\right)$, the experimental temperature, under high purity (99.99 pct) argon at a flow rate of $0.75 \mathrm{~L} / \mathrm{min}$. The gas was scrubbed by passing through ascarite and drierite prior to entering the furnace. Once the temperature has stabilized ( $\sim 10$ minutes), the slag was added to the spinel substrate. To facilitate the slag and substrate only coming in contact at the experimental temperature, the following method was developed. The solid slag is held in the Pt wire loop (number 4 in Figure 1). As it melts and becomes liquid, it remains held in the Pt wire by interfacial forces until thermal stabilization is reached. The slag is then contacted/transferred to the substrate. This technique allows the addition of slag in liquid state at the target temperature. Prior to carrying out the experiment, the substrate was leveled in the furnace using an alignment laser. This is critical to minimize gravity effects distorting the liquid. To start the experiment, the alumina support rod (number 3 in Figure 1) was lowered so that the slag contacted the $\mathrm{MgAl}_{2} \mathrm{O}_{4}$ substrate. Approximately $0.1 \mathrm{~g}$ of slag from an original $0.2 \mathrm{~g}$ was transferred to the substrate. The mass of liquid oxide added represents a compromise between errors associated with scale at small masses and using a mass that is less than the critical value of that required for gravity distortions of the droplet. ${ }^{[31]}$ The moment at which the liquid slag is contacted to the substrate and separated from the Pt wire is defined as zero time. Once the slag is added, the twin bore tube, alumina support, and $\mathrm{Pt}$ wire are withdrawn to a cold part of the furnace chamber. The distortion of the droplet as a result of removing the wire before a measurement on the droplet can be made represents an uncertainty of $\sim 0.5$ second in time zero.

The spreading of the slag on the substrate was recorded using a Sony 6.1 MP video camera (HDRSR7E). The camera was fitted with a $2 \times$ telephoto lens and 2 HOYA neutral density filters (NDX4 and NDX400) in series.

The contact angle $(\theta)$ was calculated using Eq. [1] representing the geometry of a spherical cap (see Figure $2^{[31]}$ ) from digital still images captured from the recordings

$$
\frac{\theta}{2}=\tan ^{-1} \frac{h}{a}
$$

where $R$ is the radius dissected by a base plane, $h$ is the height of contact circle, and $a$ is radius of contact circle.

The slags used were prepared by mixing laboratory grade oxides $\left(\mathrm{CaO}, \mathrm{Al}_{2} \mathrm{O}_{3}, \mathrm{SiO}_{2}\right.$, and $\left.\mathrm{MgO}\right)$ of appropriate proportions. These mixtures were then melted in a platinum crucible, quenched, and crushed. This process was repeated twice to ensure slag homogeneity. Compositions of the resultant slag, as measured by XRF, are given in Table I. C/A represents the mass pct ratio of $\mathrm{CaO} / \mathrm{Al}_{2} \mathrm{O}_{3}$. From these slags, $0.2 \mathrm{~g}$ sintered pellets were prepared and used in the sessile drop experiments.

The $\mathrm{MgAl}_{2} \mathrm{O}_{4}$ spinel powders were prepared from high purity laboratory grade $\mathrm{MgO}$ and $\mathrm{Al}_{2} \mathrm{O}_{3}(>99$ pct) starting materials by reaction sintering. These were mixed and then pressed into disks and sintered at $1873 \mathrm{~K}\left(1600{ }^{\circ} \mathrm{C}\right)$ for 24 hours. This sintered material was then crushed to a fine powder $(<38 \mu \mathrm{m})$ and re-sintered at $1998 \mathrm{~K}\left(1725^{\circ} \mathrm{C}\right)$ for 6 hours. After the second sintering, the spinel phase was confirmed by X-ray diffraction (XRD), see Figure 3. No other phases were identified via XRD. The substrates had an average apparent porosity ${ }^{[33]}$ of 1.9 pct and a spinel composition of 71.7 pet $\mathrm{Al}_{2} \mathrm{O}_{3}$ and 28.3 pet $\mathrm{MgO}$ in mass pet. All substrates were polished to $1 \mu \mathrm{m}$ finish to minimize the surface roughness difference between samples.

The substrate surface roughness was measured by using a non-contacting surface roughness measuring apparatus (Veeco Wyko NT9100 Optical Profilometer), and the mean center-line roughness $\left(R_{\mathrm{a}}\right)$ was measured. This was repeated $>20$ times on selected areas on a substrate, and an average value of $0.156 \mu \mathrm{m}$ was obtained.

Post-experiment, the sample was sectioned and prepared for electro-optical analysis. A JEOL-JSM6490 LV scanning electron microscope (SEM) with energy dispersive spectroscopy (EDS) was used.

The time at temperature and cooling effects on slag penetration into the spinel substrate were investigated by carrying out a further experiment using slag with a $\mathrm{C} / \mathrm{A}$ ratio of 0.98 . In this experiment, the slag was added as previously described. The primary difference was that 30 seconds after time zero, the furnace was opened, and 


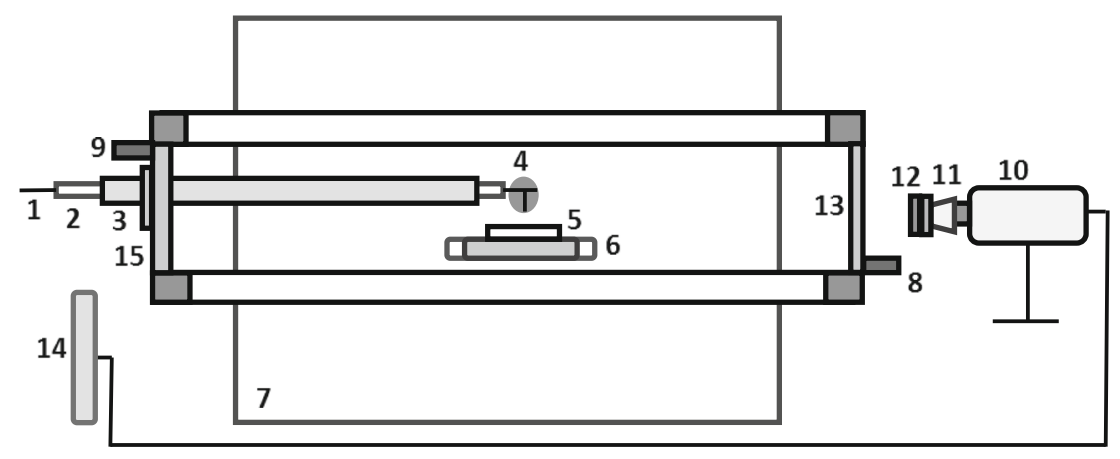

\begin{tabular}{|l|l|l|l|}
\hline 1: Pt. wire & 5: Spinel substrate & 9: Outlet gas & 13: Quartz window \\
\hline 2: Twin bore tube & 6: Tray and block & 10: Camera & 14: Monitor \\
\hline 3: Alumina support & 7: Resistance furnace & 11: $2 \mathrm{x}$ telephoto lens & 15: Flange \\
\hline $\begin{array}{l}\text { 4: Liquid slag held } \\
\text { with Pt. wire }\end{array}$ & 8: Inlet gas & 12: Filters & \\
\hline
\end{tabular}

Fig. 1-A schematic of the sessile drop apparatus.

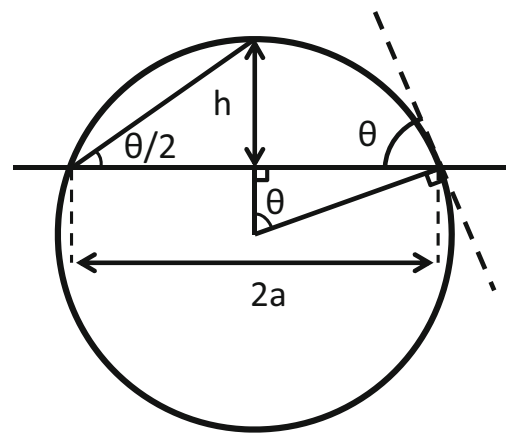

Fig. 2- Geometry of a sessile drop approximated by a spherical cap defined by radius of the base and height above basal plane.

Table I. Chemical Composition of the Experimented Slags in mass pet

\begin{tabular}{lccccc}
\hline Slag & $\mathrm{CaO}$ & $\mathrm{Al}_{2} \mathrm{O}_{3}$ & $\mathrm{SiO}_{2}$ & $\mathrm{MgO}$ & $\mathrm{C} / \mathrm{A}$ \\
\hline 1 & 41.8 & 42.7 & 9.2 & 6.3 & 0.98 \\
2 & 46.3 & 37.1 & 9.8 & 6.8 & 1.25 \\
3 & 50.9 & 32.9 & 9.5 & 6.7 & 1.55 \\
\hline
\end{tabular}

the slag-substrate couple was removed and rapidly cooled. All other experimental conditions were the same as outlined for the other experiments were the sample cooled down in the furnace. The total time this slagsubstrate couple remained in the hot zone of the furnace was $\sim 60$ seconds.

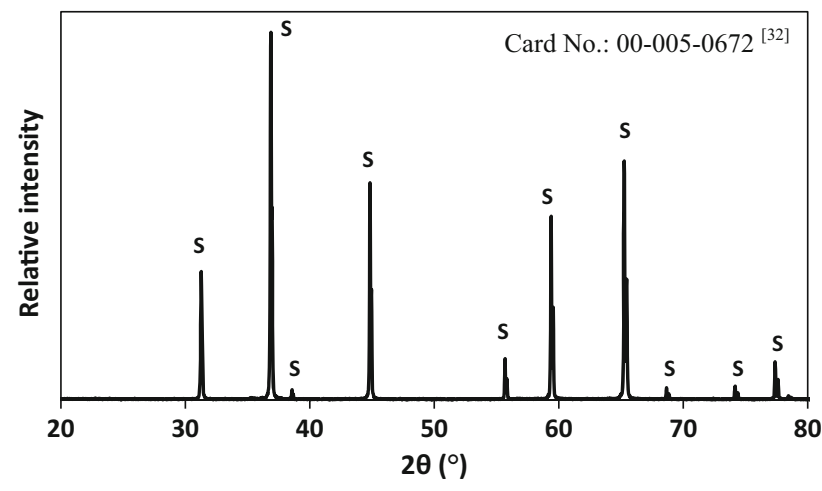

Fig. 3-The X-ray diffraction pattern for the spinel used in the preparation of the substrate. The $S$ denotes peaks as identified in card $00-005-0672 .^{[32]}$

\section{RESULTS AND DISCUSSION}

\section{A. Wetting Behavior}

A typical example of the spreading and wetting behavior of a liquid slag drop on a spinel substrate is shown in Figure 4. It can be seen that the liquid drop spreads out on the substrate within a few seconds.

The results of the wetting behavior for the slags are given in Figure 5. The data presented represent an average of a minimum of two runs per $\mathrm{C} / \mathrm{A}$ ratio tested. The $\theta$ decreased from 37.7, 28.7, and $27 \mathrm{deg}$ at time zero for the $\mathrm{C} / \mathrm{A} 0.98, \mathrm{C} / \mathrm{A} 1.25$, and $\mathrm{C} / \mathrm{A} 1.55$ slags, 


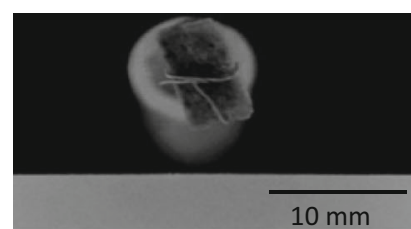

$t=-22 s$

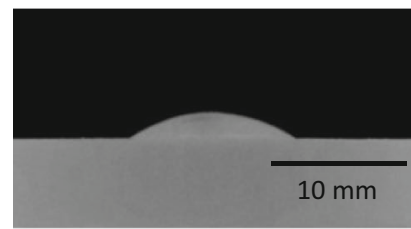

$\mathrm{t}=1 \mathrm{~s}$

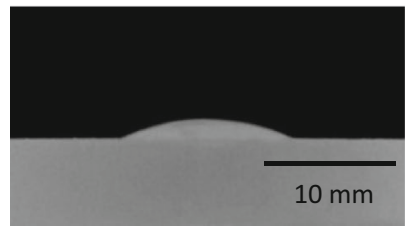

$\mathrm{t}=5 \mathrm{~s}$

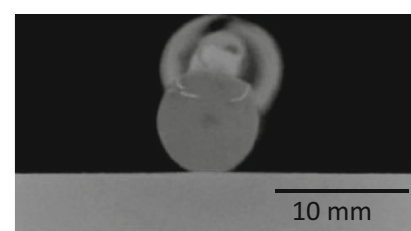

$\mathrm{t}=-2 \mathrm{~s}$

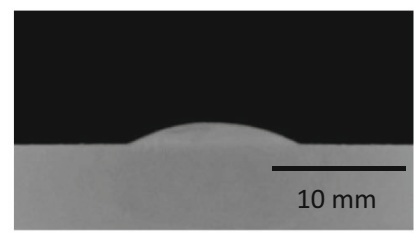

$\mathrm{t}=2 \mathrm{~s}$

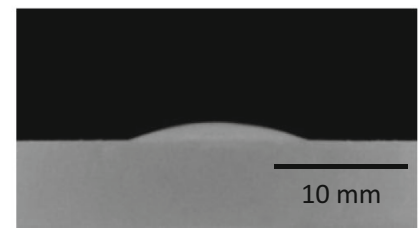

$\mathrm{t}=10 \mathrm{~s}$

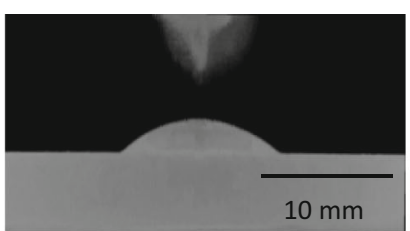

$\mathrm{t}=0 \mathrm{~s}$

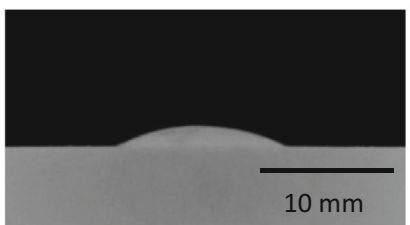

$\mathrm{t}=3 \mathrm{~s}$

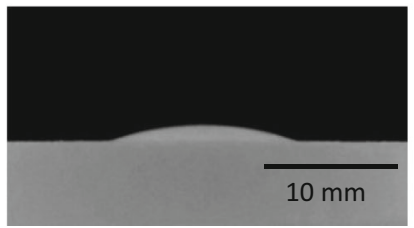

$\mathrm{t}=20 \mathrm{~s}$

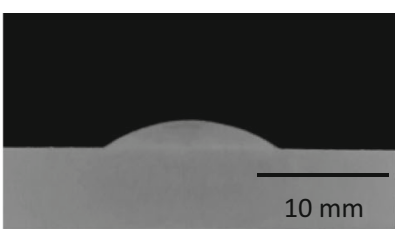

$\mathrm{t}=0.5 \mathrm{~s}$

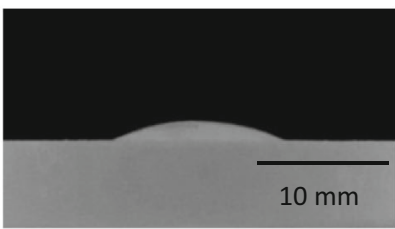

$\mathrm{t}=4 \mathrm{~s}$

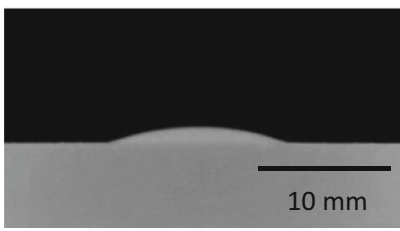

$\mathrm{t}=30 \mathrm{~s}$

Fig. 4-Spreading behavior of the slag C/A 1.25 on the spinel substrate.

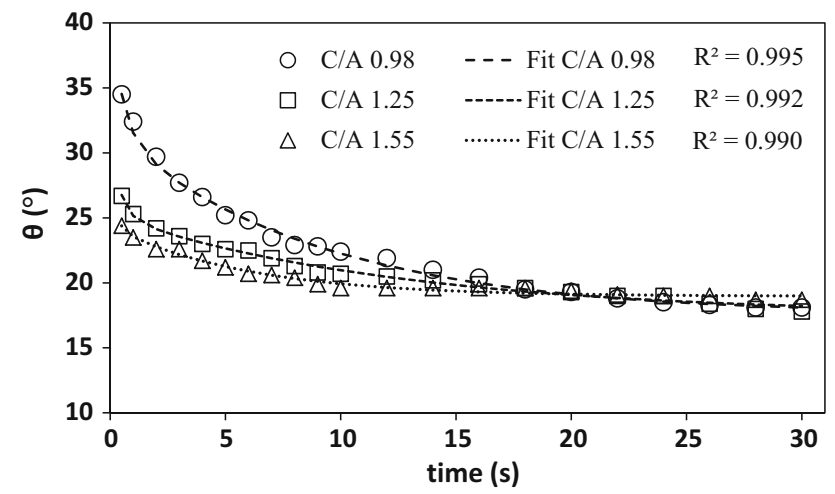

Fig. 5- $\theta$ vs time measured for slags of different $\mathrm{C} / \mathrm{A}$ ratios on a spinel substrate and application of Choi and Lee spreading model ${ }^{[20]}$ to the wetting behavior of various slags on spinel substrate.

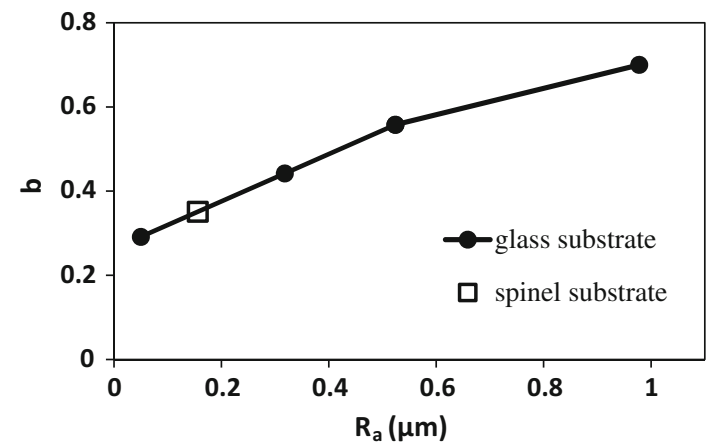

Fig. 6 - b vs $R_{\mathrm{a}}$ (substrate surface roughness). ${ }^{[20]}$

respectively, to a slag $\mathrm{C} / \mathrm{A}$ ratio independent value. After 30 seconds, at the end of the experiment, the $\theta$ was observed to be approximately $18.2 \mathrm{deg}$. This value represents an average of all data reported. It would appear that the rate of $\theta$ change in the early part of the experiment decreases with increasing $\mathrm{C} / \mathrm{A}$ ratio. The significant drop in $\theta$ in the first 6 seconds is consistent with the previous work that the authors have reported on the higher porosity $(6.7 \mathrm{pct})$ spinel material ${ }^{[3]}$ and similar to what other workers found for $\mathrm{CaO}-\mathrm{SiO}_{2}-$ $\mathrm{Al}_{2} \mathrm{O}_{3}$-based slags on alumina. ${ }^{[20]}$ The initial drop in $\theta$ is likely to be principally due to the reaction (drive to equilibrium) of the slag with the substrate and the physical properties of the slag. It may also contain a momentum component due to the slag addition technique.

\section{B. Representation of Slag Spreading Behavior}

Choi and Lee ${ }^{[20]}$ developed a model for explaining the spreading behavior of $\mathrm{CaO}-\mathrm{Al}_{2} \mathrm{O}_{3}-\mathrm{SiO}_{2}$ slags on the oxide substrates as given in the following Eq. [2]:

$$
\begin{aligned}
\cos \theta(t)= & \cos \theta_{0}+\left[\cos \theta_{\mathrm{e}, \mathrm{app}}^{\infty}-\left(\cos \theta_{\mathrm{e}, \mathrm{app}}^{\infty}-\cos \theta_{\mathrm{e}, \mathrm{app}}^{0}\right)\right. \\
& \exp (-k t)]\left[1-\exp \left(-m t^{b}\right)\right]
\end{aligned}
$$

where $\theta_{0}$ is the contact angle at $t=0, \theta_{\mathrm{e}, \mathrm{app}}^{\infty}$ is the equilibrium contact angle at $t=\infty, \theta_{\mathrm{e} \text {,app }}^{0}$ is the initial equilibrium contact angle, $k$ is constant, $m$ is related to the surface tension and viscosity of the liquid drop, and $b$ is related to surface roughness of the solid substrate.

Their approach was based on the Schroeder spreading model, ${ }^{[34]}$ the primary difference being an added term that deals with the change in equilibrium contact angle as a result of reaction between the slag and the oxide substrate. Choi and Lee ${ }^{[20]}$ carried out extensive measurements of $\mathrm{CaO}-\mathrm{Al}_{2} \mathrm{O}_{3}-\mathrm{SiO}_{2}$-based slags on solid alumina and demonstrated that their model was an 
excellent representation of their data. They showed evidence of slag penetration of their substrates but made no comment on their substrate porosity or its effect on their measurements. It would be expected that the substrate porosity of their samples is small, closed and

Table II. Fitting Parameters Obtained for Eq. [2]

\begin{tabular}{lcccc}
\hline Slag C/A & $\theta_{\text {e,app }}^{0}$ & $\theta_{\text {e,app }}^{\infty}$ & $k$ & $m$ \\
\hline 0.98 & 30.7 & 17.7 & 0.123 & 3.878 \\
1.25 & 25.0 & 17.6 & 0.088 & 5.205 \\
1.55 & 24.2 & 19.0 & 0.180 & 6.888 \\
\hline
\end{tabular}

Table III. $\sigma_{\mathrm{LV}}, \eta$, and Calculated Values of $m$ from Eq. [3]

\begin{tabular}{lccc}
\hline Slag C/A & $\sigma_{\mathrm{LV}}(\mathrm{N} / \mathrm{m})$ & $\eta\left(\mathrm{Ns} / \mathrm{m}^{2}\right)$ & $m=\frac{\sigma_{\mathrm{LV}}}{\eta}(\mathrm{m} / \mathrm{s})$ \\
\hline 0.98 & 0.597 & 0.27 & 2.2 \\
1.25 & 0.594 & 0.14 & 4.3 \\
1.55 & 0.595 & 0.08 & 7.4 \\
\hline
\end{tabular}

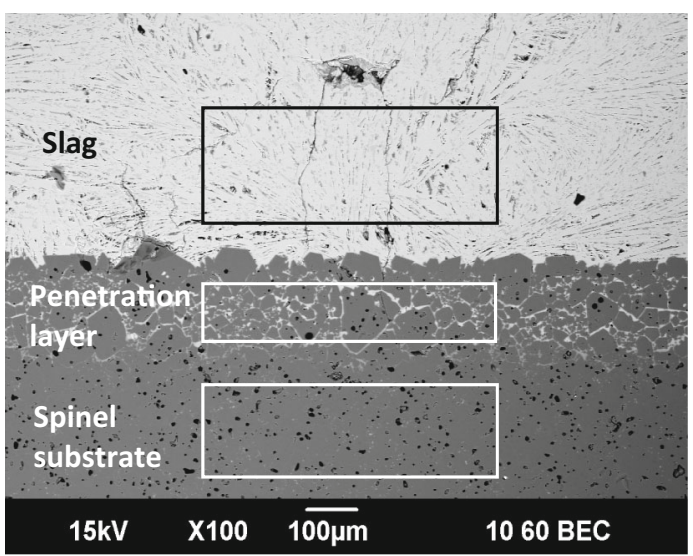

(a) comparable with that used in this study. They did assess the effects of roughness on their model/measurements. It is likely that this roughness parameter to some degree accounts for effects of porosity.

The Choi and Lee spreading approach ${ }^{[20]}$ as given in Eq. [2] was applied to the wetting data generated in this study. In order to apply their model, the factor $b$ of Eq. [2] must be evaluated for the slag-spinel substrate system used in this study. Using Choi and Lee's $b$-roughness correlation for glycerol on glass, reproduced in Figure 6, a value of $b=0.351$ was obtained for a $R_{\mathrm{a}}$ of $0.156 \mu \mathrm{m}$.

Equation [2] was then fitted to the experimental results using a non-liner regression technique, ${ }^{[35]}$ and the terms $\theta_{\mathrm{e}, \mathrm{app}}^{0}, \theta_{\mathrm{e}, \mathrm{app}}^{\infty}, \mathrm{k}$, and $\mathrm{m}$ were determined for each slag composition and are shown in Figure 5. From this figure, it can be seen that the model gives good agreement with the experimental results. The $\theta_{\mathrm{e}, \mathrm{app}}^{0}, \theta_{\mathrm{e}, \mathrm{app}}^{\infty}, k$, and $m$ values obtained are given in Table II. Given the number of fitted parameters used in fitting Eq. [2] to the wetting data perhaps it is not surprising that there is a good fit.

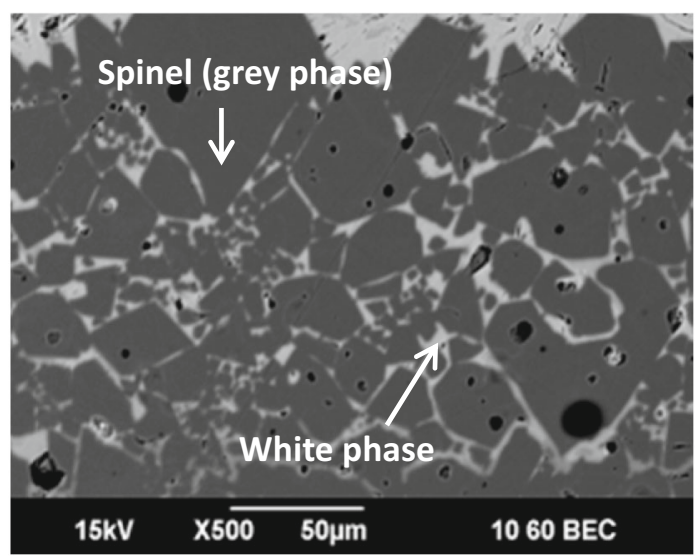

(b)

Fig. 7-(a) A cross-section micrograph of the spinel-slag C/A 0.98 showing the analyzed areas; (b) A micrograph of the spinel-slag C/A 0.98 penetration layer showing the positions of the spot analysis.

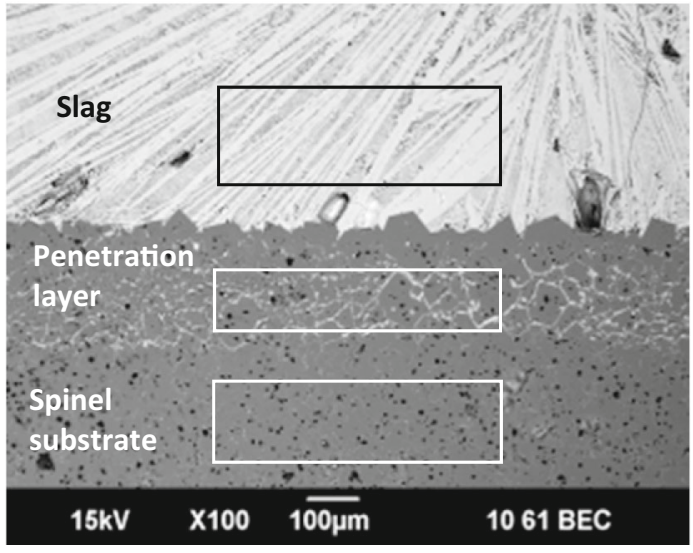

(a)

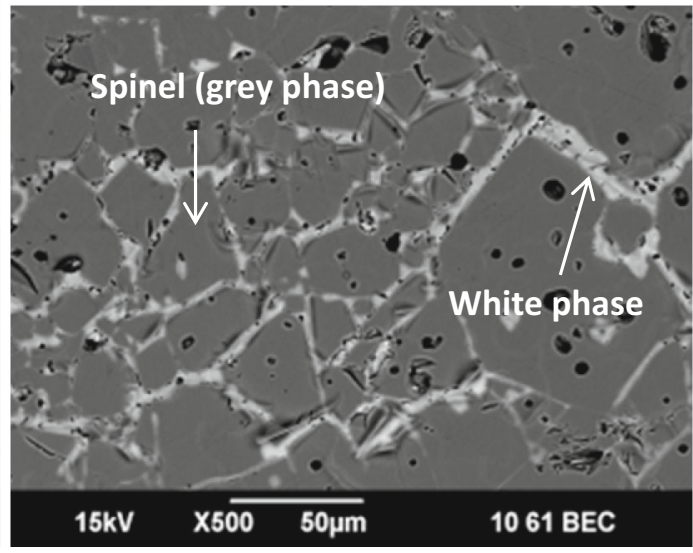

(b)

Fig. 8- (a) A cross-section micrograph of the spinel-slag C/A 1.25 showing the analyzed areas; (b) A micrograph of the spinel-slag C/A 1.25 penetration layer showing the positions of the spot analysis. 


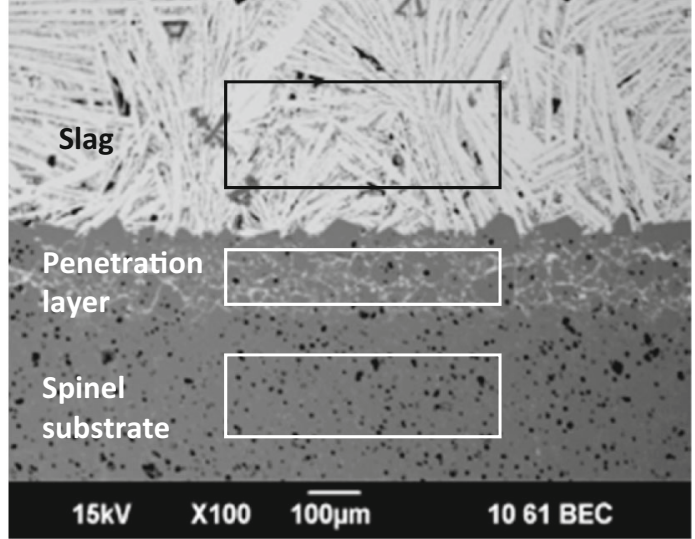

(a)

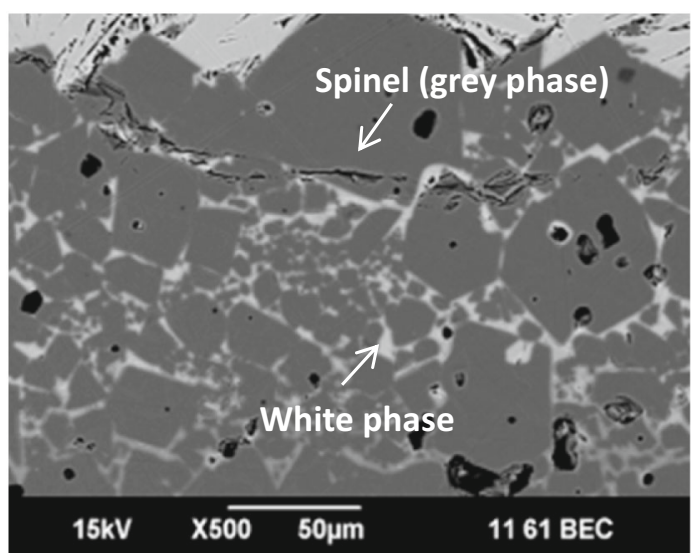

(b)

Fig. 9-(a) A cross-section micrograph of the spinel-slag C/A 1.55 showing the analyzed areas; (b) A micrograph of the spinel-slag C/A 1.55 penetration layer showing the positions of the spot analysis.

From the Schroeder model, ${ }^{[34]} m$ in Eq. [2] can be defined as

$$
m=\frac{\sigma_{\mathrm{LV}}}{\eta},
$$

where $\sigma_{\mathrm{LV}}$ is the surface tension of the slag, and $\eta$ is slag viscosity. Characteristic values for $\eta$ and $\sigma_{\mathrm{LV}}$ of the slag were calculated using the Riboud model ${ }^{[36]}$ and NPL slag model, ${ }^{[37]}$ respectively, and are given in Table III.

The values obtained for " $\mathrm{m}$ " using Eq. 2 and given in Table II, are of a similar order and in reasonable agreement with those calculated from Eq. 3, reported in Table III. They show a similar trend of increasing $\mathrm{m}$ with increasing $\mathrm{C} / \mathrm{A}$ ratio. This may indicate that the model (Eq. [2]) is more than just a convenient way to represent dynamic wetting data. It may also have use in understanding the effect of changes in the physical characteristics of slag on its wetting behavior of solid oxides. Future studies and analysis will focus on elucidating the significance of the use of Eq. [2] to represent the dynamic wetting behavior in these systems.

\section{Interfacial Characterization}

SEM characterization of the interface is given in Figures 7(a), 8(a), and 9(a) for the C/A 0.98, C/A 1.25, and $\mathrm{C} / \mathrm{A} 1.55$ slags, respectively. Inspection of these figures shows the slag penetration layer at the interface between the slag and spinel substrate. Given the changes in $\theta$, it is likely that this layer in part represents reaction between the slag and spinel substrate. It is also likely to contain a reactivity/penetration component that is associated with the cooling down period of the experiment. EDS analysis of the areas marked in Figures 7(a) through 9(a) is given in Table IV. EDS spot analyses of the penetration layer shown in Figures 7(b), 8(b), and 9(b) are given in Table V.

Comparison of the starting (original) liquid oxide compositions given in Table I with those given in Table IV indicates that while the C/A 0.98 slag remains
Table IV. EDS Analysis of Areas Intended in Figs. 7(a), 8(a), and 9(a) in mass pet

\begin{tabular}{lrrrr}
\hline $\mathrm{C} / \mathrm{A}$ & $\mathrm{CaO}$ & $\mathrm{Al}_{2} \mathrm{O}_{3}$ & $\mathrm{SiO}_{2}$ & $\mathrm{MgO}$ \\
\hline 0.98 & & & & \\
Slag & 43.4 & 42.2 & 8.4 & 6.1 \\
Penetration area & 10.5 & 64.4 & 3.0 & 22.1 \\
Spinel substrate & 0.6 & 71.7 & 2.7 & 25.0 \\
1.25 & & & & \\
Slag & 40.8 & 43.3 & 8.4 & 7.6 \\
Penetration area & 7.6 & 67.5 & 1.4 & 23.5 \\
Spinel substrate & 0.8 & 72.7 & 0.9 & 25.6 \\
1.55 & & & & \\
Slag & 43.7 & 42.4 & 6.6 & 7.3 \\
Penetration area & 9.2 & 63.9 & 3.4 & 23.6 \\
Spinel substrate & 0.5 & 72.3 & 2.8 & 24.4 \\
\hline
\end{tabular}

Table V. EDS Spot Analysis of Phases Intended in Figs. 7(b), 8(b), and 9(b) in mass pet

\begin{tabular}{lrrrr}
\hline $\mathrm{C} / \mathrm{A}$ & $\mathrm{CaO}$ & $\mathrm{Al}_{2} \mathrm{O}_{3}$ & $\mathrm{SiO}_{2}$ & $\mathrm{MgO}$ \\
\hline 0.98 & & & & \\
$\quad$ Spinel (gray phases) & 0.1 & 70.1 & 2.4 & 27.4 \\
Slag penetration (white phase) & 39.1 & 56.9 & 2.1 & 1.88 \\
1.25 & & & & \\
$\quad$ Spinel (gray phases) & 0.1 & 70.2 & 2.3 & 27.4 \\
Slag penetration (white phase) & 36.5 & 58.5 & 2.8 & 2.2 \\
1.55 & & & & \\
Spinel (gray phases) & 0.2 & 69.9 & 2.4 & 27.5 \\
Slag penetration (white phase) & 41.3 & 45.9 & 7.3 & 5.5 \\
\hline
\end{tabular}

relatively unchanged after the wetting experiment, the C/A 1.25 and 1.55 slags have become depleted in $\mathrm{CaO}$ and enriched with $\mathrm{Al}_{2} \mathrm{O}_{3}$. In the slag penetration layer, there appears to be two phases. A dark phase represents something close to the original spinel, and a white phase most likely represents slag penetration into the spinel. From Figures 7(b), 8(b) and 9(b), it would appear that the slag is penetrating through pores and along the grain boundaries. 


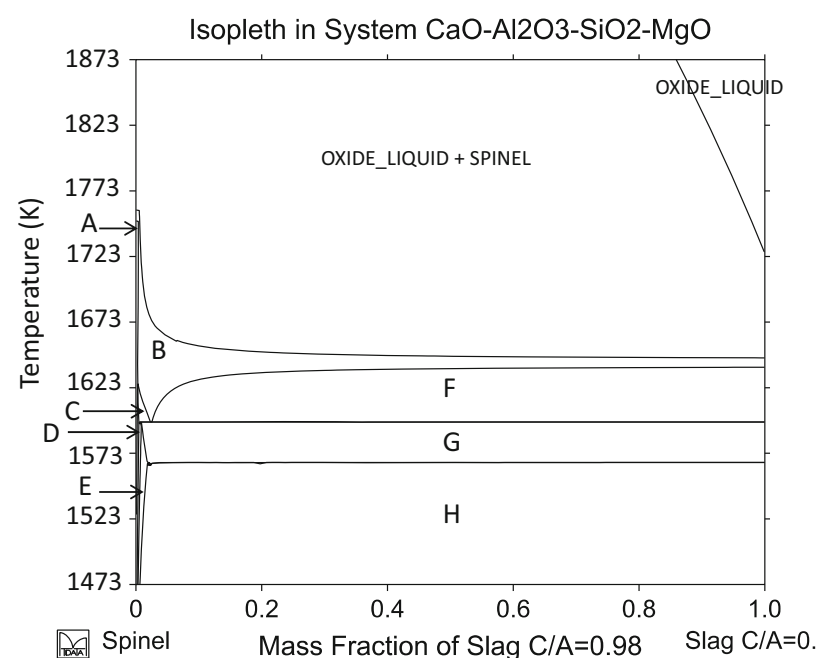

(a)

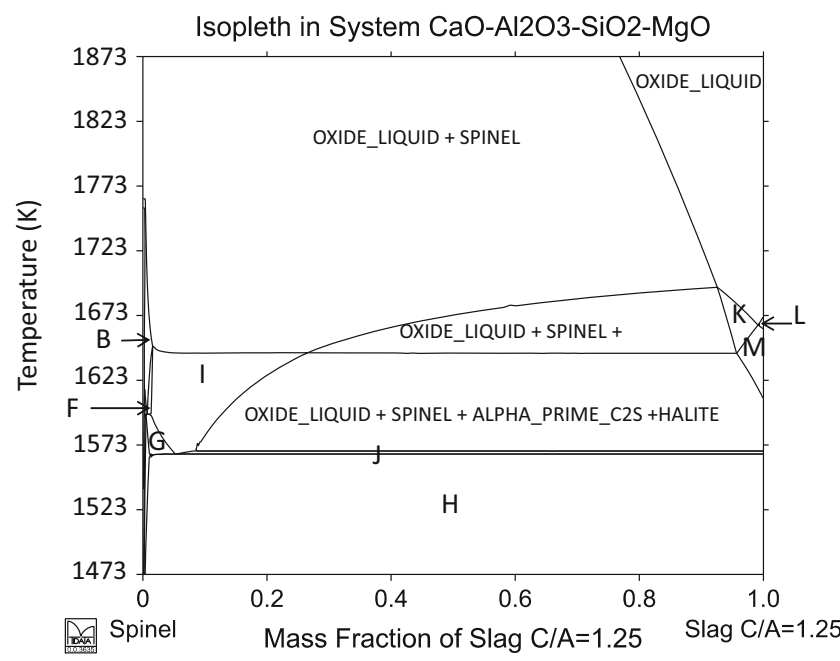

(b)

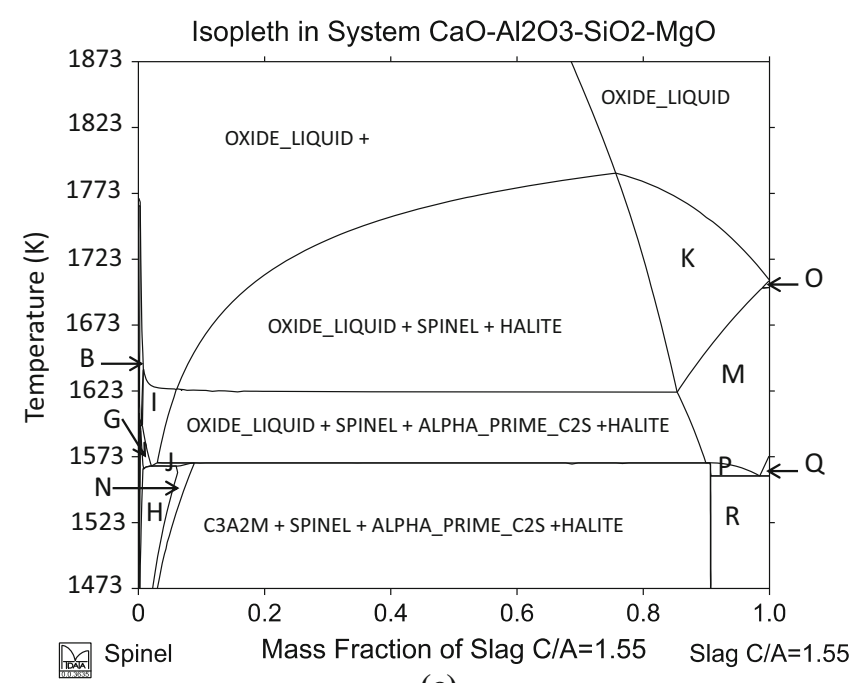

(c)

\begin{tabular}{|c|c|}
\hline Phase field & Phases present \\
\hline A & MELILITE + SPINEL \\
\hline B & OXIDE_LIQUID + MELILITE + SPINEL \\
\hline $\mathrm{C}$ & OXIDE_LIQUID + MELILITE + SPINEL + CA \\
\hline $\mathrm{D}$ & MELILITE + SPINEL + CA + ALPHA_PRIME_C2S \\
\hline $\mathrm{E}$ & SPINEL + CA + ALPHA_PRIME_C2S \\
\hline $\mathrm{F}$ & OXIDE_LIQUID + MELILITE + SPINEL+ ALPHA_PRIME_C2S \\
\hline G & OXIDE_LIQUID + SPINEL + CA + ALPHA_PRIME_C2S \\
\hline $\mathrm{H}$ & C3A2M + SPINEL + CA + ALPHA_PRIME_C2S \\
\hline I & OXIDE_LIQUID + SPINEL + ALPHA_PRIME_C2S \\
\hline $\mathrm{J}$ & C3A2M + OXIDE_LIQUID + SPINEL + ALPHA_PRIME_C2S \\
\hline $\mathrm{K}$ & OXIDE_LIQUID + HALITE \\
\hline $\mathrm{L}$ & OXIDE_LIQUID + ALPHA_PRIME_C2S \\
\hline M & OXIDE_LIQUID + ALPHA_PRIME_C2S + HALITE \\
\hline $\mathrm{N}$ & C3A2M + SPINEL + ALPHA_PRIME_C2S \\
\hline $\mathrm{O}$ & OXIDE_LIQUID + ALPHA_C2S + HALITE \\
\hline $\mathrm{P}$ & C3A2M + OXIDE_LIQUID + ALPHA_PRIME_C2S + HALITE \\
\hline Q & OXIDE_LIQUID + C3A + ALPHA_PRIME_C2S + HALITE \\
\hline $\mathrm{R}$ & C3A2M + C3A + ALPHA_PRIME_C2S + HALITE \\
\hline
\end{tabular}

Fig. 10 - The MTDATA ${ }^{[38]}$ thermodynamic calculation showing the phase stability in the (a) spinel-slag C/A 0.98, (b) spinel-slag C/A 1.25, and (c) spinel-slag C/A 1.55 system.

Thermodynamic analysis of the slag-spinel substrate systems has also been carried out using MTDATA, ${ }^{[38]}$ and the isopleths representing spinel substrate-slag C/A
$0.98,1.25$, and 1.55 are given in Figures 10(a) through (c), respectively. MTDATA is a commercial thermodynamic software package developed at the National 


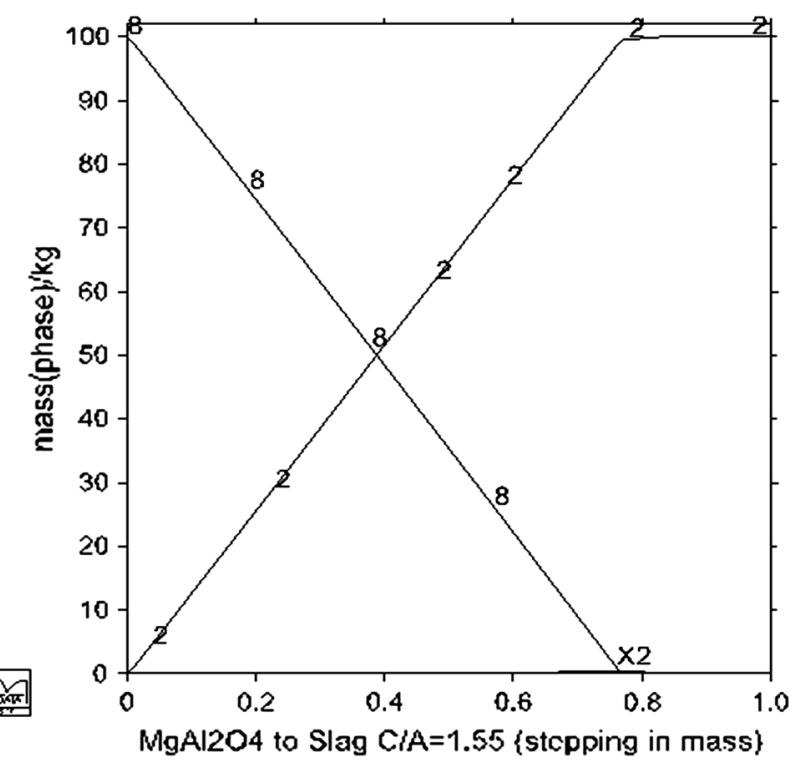

Fig. 11-MTDATA ${ }^{[38]}$ thermodynamic calculations showing the mass of phases present at different $\mathrm{MgAl}_{2} \mathrm{O}_{4}$ to slag $\mathrm{C} / \mathrm{A} 1.55$ mass ratios at $1773 \mathrm{~K}\left(1500{ }^{\circ} \mathrm{C}\right)$, where $2=$ oxide liquid, $8=$ spinel, and $\mathrm{X} 2=$ halite.

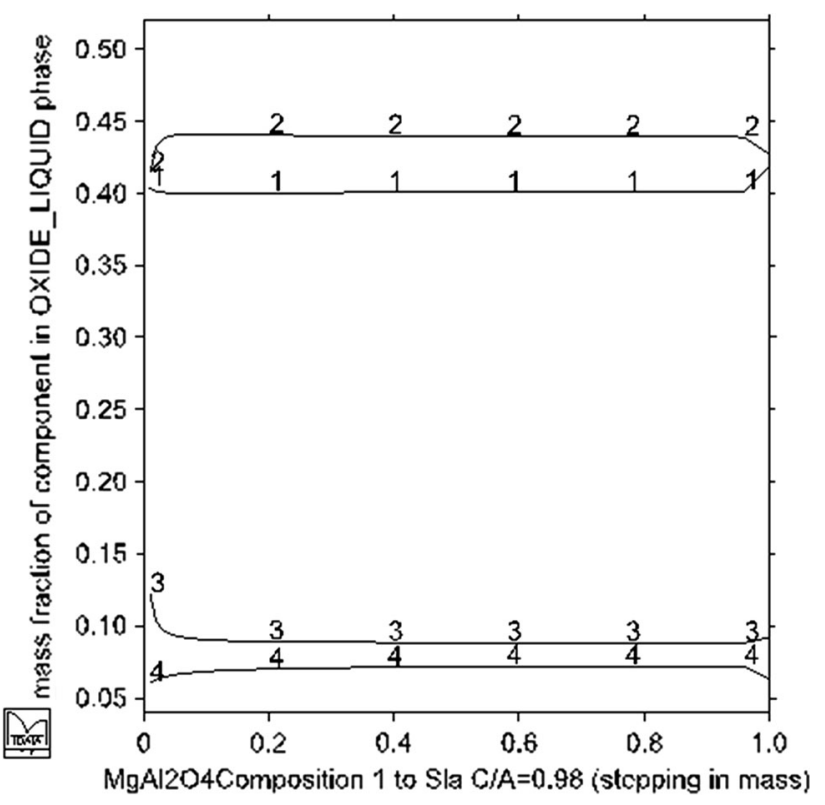

Fig. 12-MTDATA ${ }^{[38]}$ thermodynamic calculations showing the mass fraction of components in the liquid oxide phase at different $\mathrm{MgAl}_{2} \mathrm{O}_{4}$ to slag $\mathrm{C} / \mathrm{A} 0.98$ mass ratios at $1773 \mathrm{~K}\left(1500{ }^{\circ} \mathrm{C}\right)$ where $1=\mathrm{CaO}, 2=\mathrm{Al}_{2} \mathrm{O}_{3}, 3=\mathrm{SiO}_{2}, 4=\mathrm{MgO}$.

Physical Laboratory in the U.K. that is able to calculate complex multi-component phase equilibria in gasliquid-solid systems. It uses a Gibbs Energy minimization routine to establish the thermodynamic equilibrium of a defined system.

From Figures 10(a) and (b), it can be seen that at the experimental temperature $\left[1773 \mathrm{~K}\left(1500{ }^{\circ} \mathrm{C}\right)\right]$, the spinel phase and oxide liquid (slag) phase are stable. In Figure 10(c) for the C/A, $1.55 \mathrm{slag}$, spinel phase, oxide

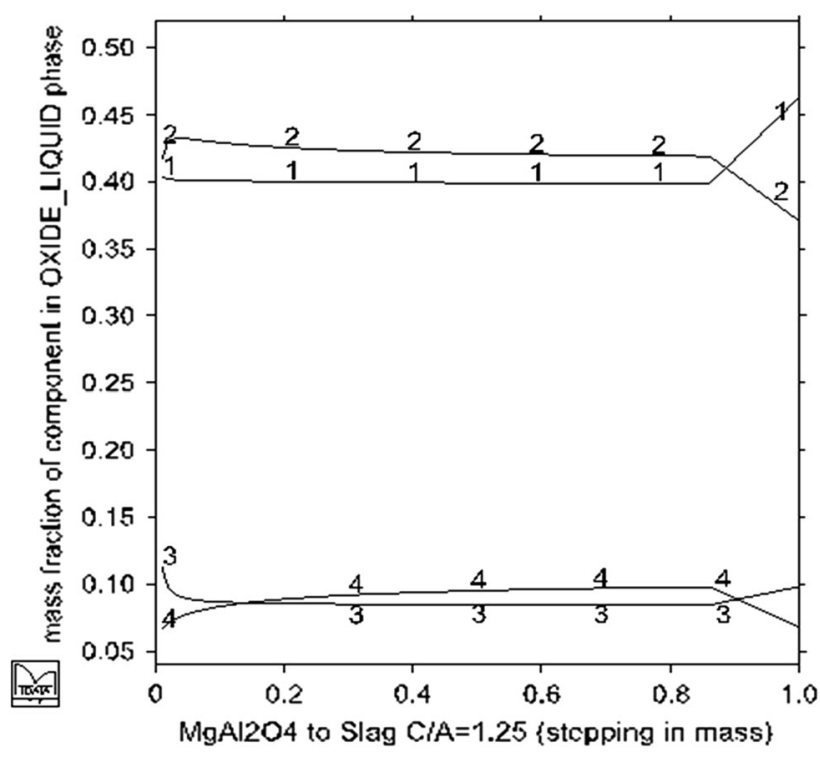

Fig. 13-MTDATA ${ }^{[38]}$ thermodynamic calculations showing the mass fraction of components in the liquid oxide phase at different $\mathrm{MgAl}_{2} \mathrm{O}_{4}$ to slag $\mathrm{C} / \mathrm{A} 1.25$ mass ratios at $1773 \mathrm{~K}\left(1500{ }^{\circ} \mathrm{C}\right)$ where $1=\mathrm{CaO}, 2=\mathrm{Al}_{2} \mathrm{O}_{3}, 3=\mathrm{SiO}_{2}, 4=\mathrm{MgO}$.

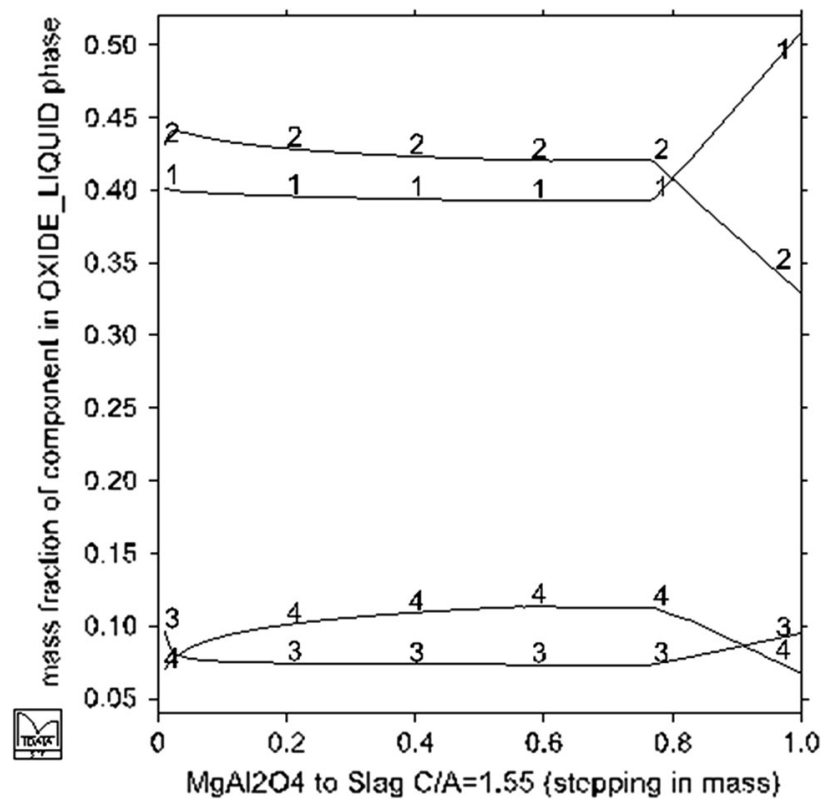

Fig. 14-MTDATA ${ }^{[38]}$ thermodynamic calculations showing the mass fraction of components in the liquid oxide phase at different $\mathrm{MgAl}_{2} \mathrm{O}_{4}$ to slag $\mathrm{C} / \mathrm{A} 1.55$ mass ratios at $1773 \mathrm{~K}\left(1500{ }^{\circ} \mathrm{C}\right)$ where $1=\mathrm{CaO}, 2=\mathrm{Al}_{2} \mathrm{O}_{3}, 3=\mathrm{SiO}_{2}, 4=\mathrm{MgO}$.

liquid (slag), and halite $(\mathrm{MgO})$ phases are stable. The phases predicted are broadly consistent with the EDS analysis (Tables IV and V) of the penetration layer that showed a two phase region. The darker phase is consistent with the original spinel and the white phase is consistent with the oxide liquid (slag) phase. To understand why no halite $(\mathrm{MgO})$ phase has been identified as predicted in Figure 10(c) for the C/A, 1.55 slag requires more detailed analysis. 
A more detailed thermodynamic analysis of the phases formed at $1773 \mathrm{~K}\left(1500{ }^{\circ} \mathrm{C}\right)$ for the $\mathrm{C} / \mathrm{A} 1.55$ is given in Figure 11. From Figure 11, it can be seen that, for mass ratios of $\mathrm{MgAl}_{2} \mathrm{O}_{4}$ to slag up to $\sim 0.76$, the amount of spinel is linearly decreasing and inversely proportional to the liquid oxide phase. After this point, it is primarily liquid oxide that is stable. The amount of halite $(\mathrm{MgO})$ phase predicted to form, shown in Figure 11, reached a maximum of $\sim 0.6$ pct by mass and was only stable over a very limited spinel-slag mixture range. Given this small value and the limitations of EDS analysis, it is not surprising that the $\mathrm{MgO}$ phase was not found in the penetration layer of the C/A 1.55 slag.

The change in mass fraction of the slag components (change in slag composition) of all the stable phases at $1773 \mathrm{~K}\left(1500{ }^{\circ} \mathrm{C}\right)$ for three slag-spinel substrate systems was also evaluated using MTDATA. ${ }^{[38]}$ There was little change predicted in the composition of the spinel and halite phases, as such they are not reproduced here. The slag phase, however, and in particular the slag phase in the C/A 1.55 slag-spinel system, was predicted to change (see Figures 13 and 14). From the thermodynamic analysis, it was expected that there would be an increase

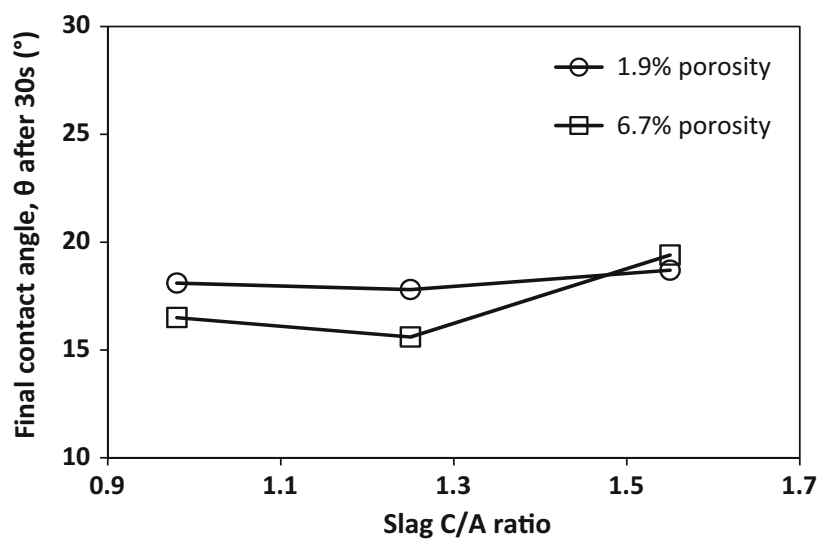

Fig. 15-The effect of substrate porosity on final contact angle.

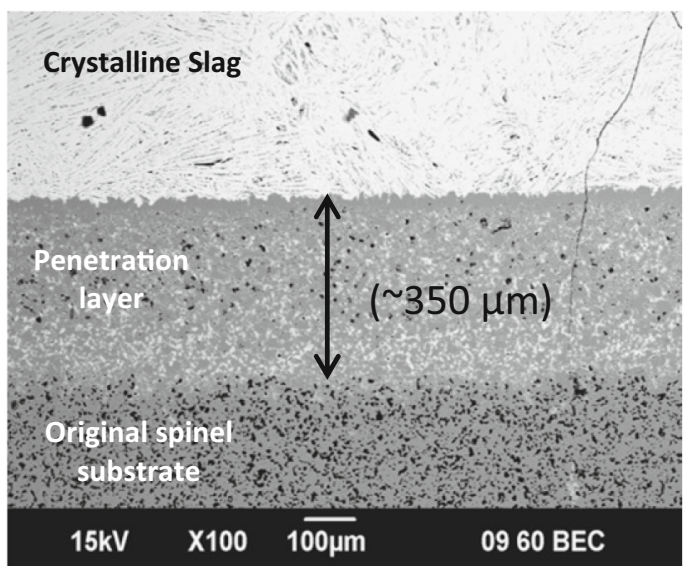

(a) in the $\mathrm{Al}_{2} \mathrm{O}_{3}$ of the slags and a decrease in the $\mathrm{CaO}$ of the slag. These changes is being the modest in C/A 0.98 slag (Figure 12) but increasing with $\mathrm{C} / \mathrm{A}$ ratio of the slag (Figures 13 and 14). This is broadly consistent with the slag analysis given in Tables IV and V. Though the C/A 0.98 slag showed little change in the slag composition (Tables IV and V) before and after the experiment, this is likely due to uncertainties in the EDS analysis, a lower driving force for reaction as the $\mathrm{Al}_{2} \mathrm{O}_{3}$ and $\mathrm{CaO}$ contents of the slag are close to the equilibrium values or some combination of these.

\section{Effect of Substrate Porosity on Wetting and Penetration Layer}

To understand the effect of substrate porosity on wetting behavior of the slag, the results of this study using a substrate of low porosity (1.9 pct) spinel were compared with the previous work of the authors ${ }^{[3]}$ on higher porosity $(6.7 \mathrm{pct})$ spinel substrates. The same trend was observed with respect to the changes in wetting with time and slag composition at both substrate porosities. In both cases, the contact angle decreased rapidly in the first 10 seconds to a plateau value at the extended times. An evaluation of the final contact ( $\theta$ after 30 seconds) given in Figure 15, showed no significant effect on contact angle either.

From SEM and EDS analyses, the slag penetrated layer in 1.9 pct-pores spinel substrate appeared two phase and consisted of original spinel and a modified slag phase. This is very similar to characteristics of slag penetration layer previously reported on the high porosity spinel. ${ }^{[3]}$ The primary difference with respect to porosity is the depth of penetration of the slag. Figure 16 shows the depth of penetration layer of $\mathrm{C} / \mathrm{A}$ 0.98 slag decreased from $\sim 350 \mu \mathrm{m}$ for higher porosity substrate to $\sim 190 \mu \mathrm{m}$ for lower porosity spinel substrate. The depth of penetration shows a similar trend for the other slags used in this study. While the primary focus of the porosity effects was an attempt to assess the limitations of the quality of the substrate used on the

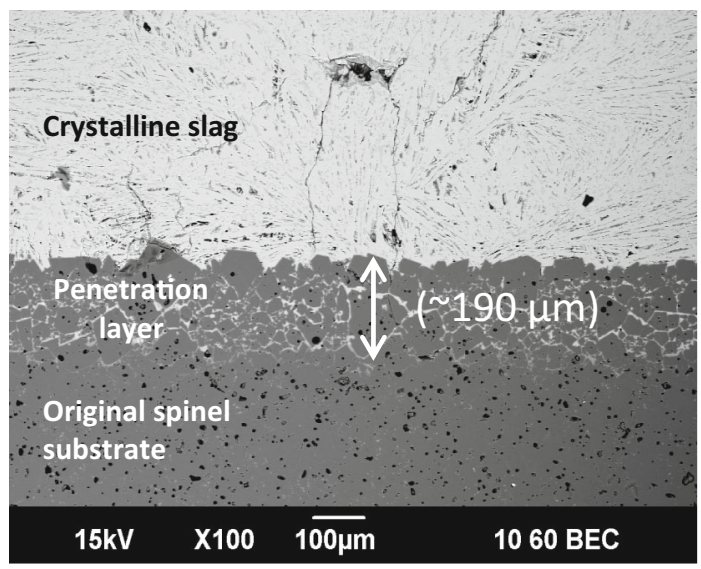

(b)

Fig. 16-(a) The thicknesses of penetration layer of C/A 0.98 slag on high porosity (6.7 pct) spinel substrate; (b) the thicknesses of penetration layer of C/A 0.98 slag on low porosity (1.9 pct) spinel substrate. 


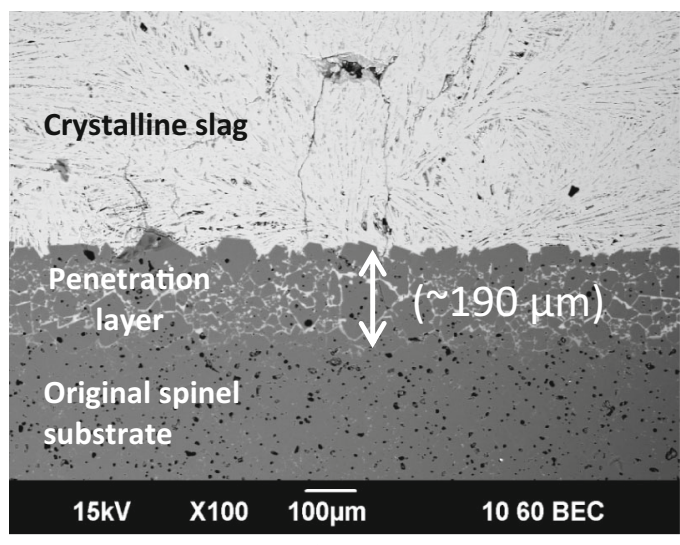

(a)

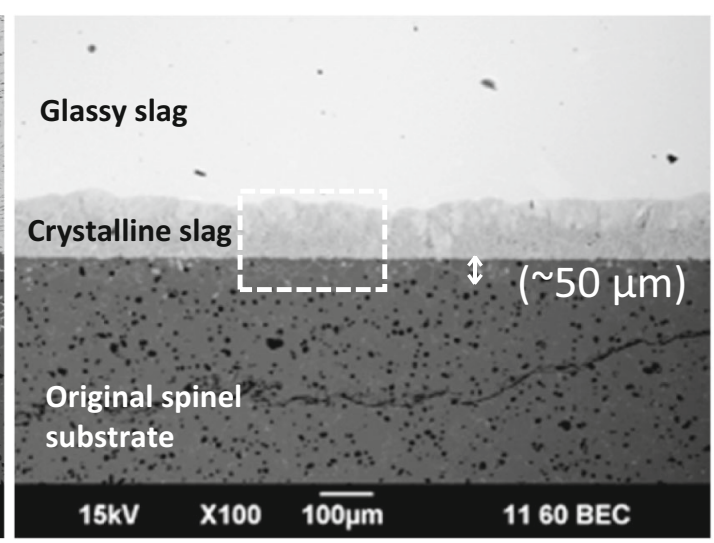

(b)

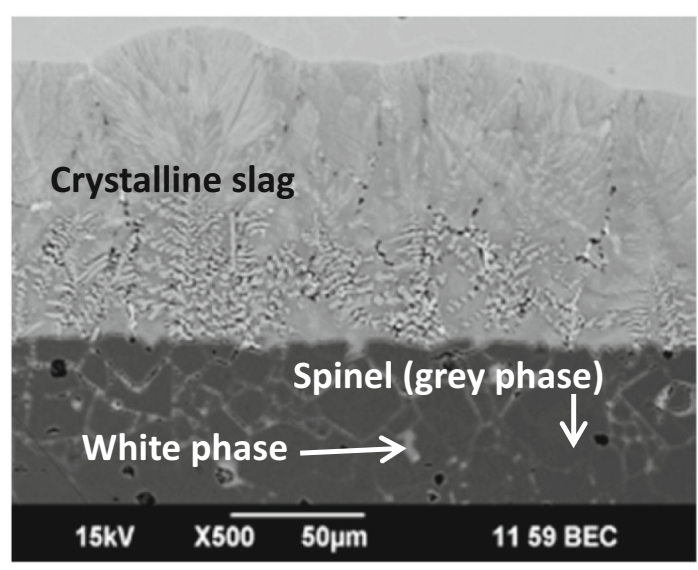

(c)

Fig. 17- (a) The thickness of the penetration layer for C/A 0.98 slag under standard measurement conditions and (slow) cooled in the furnace; (b) the thickness of the penetration layer for C/A 0.98 slag where the sample was removed from the furnace in $\sim 60 \mathrm{~s}$ after time zero and (rapid) cooled on laboratory bench; $(c)$ A higher magnification image of the dashed area marked in Fig. 16(b), showing the slag penetration and the positions of spot analysis for the spinel slag C/A 0.98 .

Table VI. EDS Spot Analysis of Phases in Fig. 17c

\begin{tabular}{lrccr}
\hline Location/Phases & $\mathrm{CaO}$ & $\mathrm{Al}_{2} \mathrm{O}_{3}$ & $\mathrm{SiO}_{2}$ & $\mathrm{MgO}$ \\
\hline Spinel (gray phases) & 0.1 & 69.7 & 2.6 & 27.6 \\
Slag penetration (white phase) & 42.6 & 47.0 & 7.6 & 2.8 \\
\hline
\end{tabular}

Values are in mass pct.

wetting measurements, it does provide some insight into how certain types of inclusion might react with the slag. For inclusions with a dendritic structure and/or that are highly agglomerated ${ }^{[39-41]}$ the wetting values measured and penetration of the substrates observed would indicate that the voids and valleys in these inclusions could be penetrated.

Using a simple model developed for slag penetration into refractory pores given in Eq. [4], ${ }^{[42]}$

$$
l^{2}=\left(r \cos \frac{\theta}{2}\right)\left(\frac{\sigma}{\eta}\right) t
$$

where $l$ is slag penetration depth, $r$ is pore radius, and $t$ is time, the effects of changing $\theta$ on penetration depth, $l$, can be assessed. From Eq. [4], it can be seen that for all other factors being equal a lower wetting angle (more wetting condition), $l$ the penetration depth is increased. While the use of Eq. [4] gives an insight into how $l$ changes with $\theta$, the constant $r$ value is likely to be an oversimplification for an inclusion, but the general point regarding penetration is valid. This increased penetration would lead to a stronger slag-inclusion bond through increased contact area of the slag and inclusion.

\section{E. Effect of Cooling Time on the Penetration Layer}

Comparison of the slag-substrate interface at the end of the experiment under the two different cooling regimes (slow cooled in the furnace $v s$ rapid cooled on the bench top) is given in Figure 17 for the C/A 0.98 slag. From Figures 17(a) and (b), it can be seen that there is a decrease in the depth of slag penetration from $\sim 190$ to $\sim 50 \mu \mathrm{m}$ for the slow- and rapid-cooled samples, respectively. A higher magnification image of the area marked with a dashed box in Figure 17(b), showing the slag penetration is given in Figure 17(c). The positions of the EDS spot analyses for the spinel (gray phase) and slag (white phase) are also shown in Figure 17(c). The respective EDS compositions are given in Table VI. The composition of the dark phase represents something 
close to the original spinel, and the white phase is similar to that of the starting slag but is enriched of alumina and depleted of magnesia. The differences in crystallinity shown in Figures 17(a) and (b) are likely to be related to the cooling rate. The faster cooled sample has a significant glassy component. The slag structures shown, from the interface out to the slag bulk, are unlikely to be representative of the structure at the experimental temperature. As at this temperature, the slag would be expected to be primarily liquid. The majority of the dark features seen in the slag bulk are voids.

From these data, it can be seen that the slag is penetrating/reacting with the spinel substrates even at the short timescales. This would indicate that the penetration effect is not simply an experimental artifact. This is likely to be significant for inclusion removal, where an inclusion has to bond/react with the slag prior to its dissolution in the slag. It is likely that this penetration would lead to a stronger bond through increased contact area with the slag for inclusions of a dendritic or agglomerated nature and therefore more efficient removal from the liquid steel.

\section{CONCLUSIONS}

In a study to investigate slag reactivity with inclusions, a series of dynamic wetting measurements, mathematical modeling of slag spreading behavior, and thermodynamic analysis of slags in the $\mathrm{CaO}-\mathrm{Al}_{2} \mathrm{O}_{3}-$ $\mathrm{SiO}_{2}-\mathrm{MgO}$ system on a $\mathrm{MgAl}_{2} \mathrm{O}_{4}$ spinel substrate was carried out. The key findings were

1. The contact angle $(\theta)$ of the slag on the substrate decreases rapidly in the first 10 seconds to a plateau value at extended times. The contact angle $(\theta)$ decreased from 37.7, 28.7, and 27 deg at time zero for the C/A 0.98, C/A 1.25, and C/A 1.55 slags, respectively, to a slag concentration-independent value. After 30 seconds, at the end of the experiment, this value was $\sim 18.2 \mathrm{deg}$. The Choi and Lee ${ }^{[20]}$ method of representing the spreading behavior of slags on oxide substrates was successfully applied and should prove useful in representing large datasets.

2. There was evidence of the slag penetrating the substrate via pores and along grain boundaries, forming a reaction/penetration layer on the substrate. From SEM and EDS analyses, this penetrated layer appeared two phase and consisted of something close to the original spinel and a modified slag phase.

3. Thermodynamic modeling of the slag-spinel substrate system was broadly consistent with the EDS analysis of the penetrated layer and post reacted slag.

4. The slag wetting behavior is not a strong function of substrate porosity. No obvious change was observed in final contact angle of the slags on the spinel substrate when their porosity changed from 6.7 to 1.9 pct.

5. The slag penetrates/reacts with the spinel substrates even at the short timescales. This is likely to be significant for inclusion removal, where an inclusion has to bond/react with the slag prior to its dissolution in the slag.

\section{ACKNOWLEDGMENTS}

The support of BlueScope Steel and the use of the Australian Research Council funded JEOL-JSM6490 LV SEM at the UOW Electron Microscopy Centre is acknowledged.

\section{REFERENCES}

1. J.H. Lowe and A. Mitchell: Clean Steel, Institute of Materials, London, 1995, pp. 223-32.

2. B. Deo and R. Boom: Fundamentals of Steelmaking Metallurgy, Prentice Hall International, New York, 1993, pp. 254-69.

3. H. Abdeyazdan, N. Dogan, M.A. Rhamdhani, M. Chapman, and B.J. Monaghan: Materials Science and Technology Conference, Toronto, Canada, AIST, Warrendale, 2013, pp. 507-14.

4. L. Jonsson and P. Jönsson: ISIJ Int., 1996, vol. 36, pp. 1127-34.

5. L. Zhang, S. Taniguchi, and K. Matsumoto: Ironmak. Steelmak., 2002, vol. 29, pp. 326-36.

6. Y. Miki, H. Kitaoka, T. Sakuraya, and T. Fujii: ISIJ Int., 1992, vol. 32, pp. 142-49.

7. B.J. Monaghan and L. Chen: Ironmak. Steelmak., 2006, vol. 33, pp. $323-30$.

8. B.J. Monaghan, L. Chen, and J. Sorbe: Ironmak. Steelmak., 2005, vol. 32 , pp. $258-64$

9. K.H. Sandhage and G.J. Yurek: J. Am. Ceram. Soc., 1991, vol. 74, pp. 1941-54.

10. S. Sridhar and A.W. Cramb: Metall. Trans. B, 2000, vol. 31, pp. 406-10.

11. M. Valdez, K. Prapakorn, A.W. Cramb, and S. Seetharaman: Steel Res. Int., 2001, vol. 72, pp. 291-97.

12. M. Valdez, K. Prapakorn, A.W. Cramb, and S. Sridhar: Ironmak. Steelmak., 2002, vol. 29, pp. 47-52.

13. X. Yu, R.J. Pomfret, and K.S. Coley: Metall. Mater. Trans. B, 1997, vol. 28B, pp. 275-79.

14. K.H. Sandhage and G.J. Yurek: J. Am. Ceram. Soc., 1998, vol. 7, pp. 478-89.

15. K.H. Sandhage and G.J. Yurek: J. Am. Ceram. Soc., 1990, vol. 73, pp. $3633-42$.

16. K.H. Sandhage and G.J. Yurek: J. Am. Ceram. Soc., 1990, vol. 73, pp. $3643-49$

17. S. Taira, K. Nakashima, and K. Mori: ISIJ Int., 1993, vol. 33, pp. 116-23.

18. K. Ueda: Mater. Trans. JIM, 1999, vol. 40, pp. 989-93.

19. S. Seetharaman, ed.: Fundamentals of Metallurgy, Woodhead Publishing in Materials, Cambridge, England, 2008, pp. 23-25.

20. J.Y. Choi and H.G. Lee: ISIJ Int., 2003, vol. 43, pp. 1348-55.

21. H. Todoroki and S. Inada: Bull. Iron Steel Inst. Jpn, 2003, vol. 8, pp. 575-80.

22. J.H. Park and H. Todoroki: ISIJ Int., 2010, vol. 50, pp. 1333-46.

23. L. Frank: Iron Steelmak., 1999, vol. 26, pp. 33-39.

24. G.J.W. Kor: First International Calcium Treatment Symposium, Glasgow, UK, The Institute of Metals, London, U.K., 1988, pp. 39-44.

25. N. Verma, P. Pistorius, R. Fruehan, M. Potter, H. Oltmann, and E. Pretorius: Metall. Mater. Trans. B, 2012, vol. 43B, pp. 830-40.

26. N. Dogan, R.J. Longbottom, M.H. Reid, M.W. Chapman, P. Wilson, L. Moore, and B.J. Monaghan: Ironmak. Steelmak., 2014, accepted.

27. M. Jiang, X. Wang, B. Chen, and W. Wang: ISIJ Int., 2010, vol. 50, pp. 95-104.

28. S. Yang, Q. Wang, L. Zhang, J. Li, and K. Peaslee: Metall. Mater. Trans. B, 2012, vol. 43B, pp. 731-50.

29. C.W. Seo, S.H. Kim, S.K. Jo, M.O. Suk, and S.M. Byun: Metall. Mater. Trans. B, 2010, vol. 41B, pp. 790-97. 
30. T. Nishi and K. Shinme: Tetsu-to-Hagane, 1998, vol. 84, pp. 837-43.

31. N. Eustathopoulos, M.G. Nicholas, and B. Drevet: Wettability at High Temperatures, Elsevier, Oxford, 1999, pp. 106-47.

32. J.G. Swanson and R.K. Fuyat: Natl. Bur. Stand (U.S.) Circ., 1953, vol. 539(11), p. 35.

33. A. 1774.5 Method 5: The Determination of Density Porosity and Water Adsorption in Refractories and Refractory Materials, Standards Australia, 2004.

34. L.W. Schroeder: Contact Angle, Wettability and Adhesion, CRC Press, Boca Raton, 1993, pp. 349-59.

35. Excel, Microsoft Office, Version 14.0.6106.5005 (32-bit), 2010

36. P.V. Riboud, Y. Roux, L. Lucas, and H. Gaye: Fachber. Hüttenpraxis Metallweiterverarbeitung, 1981, vol. 19, pp. 859-69.
37. K. Mills: National Physical Laboratory, 1.07 edn., U.K., 1991.

38. R.H. Davies, A.T. Dinsdale, J.A. Gisby, J.A.J. Robinson, and S.M. Martin: CALPHAD, 2002, vol. 26, pp. 229-71.

39. A.W. Cramb, ed.: The Making, Shaping and Treating of Steel, $11^{\text {th }}$ ed., Casting Volume, AIST, Warrendale, 2010, pp. 65-84.

40. R.J. Fruehan, ed.: The Making, Shaping and Treating of Steel, $11^{\text {th }}$ ed., Steelmaking and Refining Volume, AIST, Warrendale, 2012, pp. 687-93.

41. L. Hong, W. Xinhua, Y. Sasaki, and M. Hino: Mater. Trans., 2007, vol. 48, pp. 2170-73.

42. W.E. Lee and S. Zhang: Int. Mater. Rev., 1999, vol. 44, pp. 77-104. 